Article

\title{
Preparation, Antioxidant and Immunoregulatory Activities of a Macromolecular Glycoprotein from Salvia miltiorrhiza
}

\author{
Hai-Yu Ji ${ }^{1}{ }^{\circledR}$, Ke-Yao Dai ${ }^{1}$, Chao Liu ${ }^{1}$, Juan Yu ${ }^{1}$, Xiao-Yu Jia ${ }^{2,3, *}$ and An-Jun Liu ${ }^{1}$ \\ 1 College of Food Science and Engineering, Tianjin University of Science and Technology, Tianjin 300457, China; \\ haiyu11456@tust.edu.cn (H.-Y.J.); $19847910 @$ mail.tust.edu.cn (K.-Y.D.); 21942016@mail.tust.edu.cn (C.L.); \\ yujuan14615@tust.edu.cn (J.Y.); laj@tust.edu.cn (A.-J.L.) \\ 2 Tianjin Key Laboratory of Postharvest Physiology and Storage of Agricultural Products, Key Laboratory of \\ Storage of Agricultural Products, National Engineering Technology Research Center for Preservation of \\ Agricultural Products, Ministry of Agriculture and Rural Affairs, Tianjin 300384, China \\ 3 State Key Laboratory of Food Nutrition and Safety, Tianjin University of Science and Technology, \\ Tianjin 300457, China \\ * Correspondence: 17908008@mail.tust.edu.cn; Tel.: +86-183-2269-3795
}

Citation: Ji, H.-Y.; Dai, K.-Y.; Liu, C.; Yu, J.; Jia, X.-Y.; Liu, A.-J. Preparation, Antioxidant and Immunoregulatory Activities of a Macromolecular Glycoprotein from Salvia miltiorrhiza. Foods 2022, 11, 705. https:// doi.org/10.3390/foods11050705

Received: 4 February 2022

Accepted: 23 February 2022

Published: 27 February 2022

Publisher's Note: MDPI stays neutral with regard to jurisdictional claims in published maps and institutional affiliations.

Copyright: (C) 2022 by the authors. Licensee MDPI, Basel, Switzerland. This article is an open access article distributed under the terms and conditions of the Creative Commons Attribution (CC BY) license (https:// creativecommons.org/licenses/by/ $4.0 /)$.

\begin{abstract}
Salvia miltiorrhiza has exhibited various bioactive functions due to the existence of polysaccharides, hydrophilic phenolic acids, diterpenoid quinones, and essential oils. However, little research has reported the glycoprotein preparation and corresponding bioactivities. In this study, the water-soluble glycoprotein from S. miltiorrhiza roots was firstly isolated with the extraction process optimized by response surface methodology, and then, the preliminary structural properties, and the antioxidant and immunoregulatory activities were investigated. Results showed that the extraction conditions for higher extraction yields were identified as follows: ultrasonic power of $220 \mathrm{~W}$, ultrasonic time of $2.0 \mathrm{~h}$, extraction temperature of $60^{\circ} \mathrm{C}$, liquid/solid ratio of $20 \mathrm{~mL} / \mathrm{g}$, and the glycoprotein yields of $1.63 \pm 0.04 \%$. Structural analysis showed that the glycoprotein comprised protein and polysaccharide (contents of $76.96 \%$ and $20.62 \%$, respectively), with an average molecular weight of $1.55 \times 10^{5} \mathrm{Da}$. Besides, bioactivities analysis showed that the glycoprotein presented strong scavenging effects on multiple free radicals, and effectively enhanced the antioxidant enzyme activities and immunological indicators in cyclophosphamide-induced immunocompromised mice dose-dependently. These data demonstrated that S. miltiorrhiza glycoprotein presented the potential to be a novel edible functional compound, and could be practically applied in the food industry.
\end{abstract}

Keywords: S. miltiorrhiza glycoprotein; optimization; structural properties; bioactivities

\section{Introduction}

Salvia miltiorrhiza (named Danshen in Chinese) has been used for treating cerebrovascular and cardiovascular diseases through promoting blood circulation and removing blood stasis in vivo [1,2]. The primary bioactive materials in S. miltiorrhiza mainly comprise polysaccharides, hydrophilic phenolic acids, diterpenoid quinones, and essential oils, which contribute to the various bioactivities, including antioxidant, anticoagulation, antihyperlipidemia, etc. [3-5]. As reported, distilled water is generally used for protein and polysaccharide extraction from multiple raw materials, and various auxiliary conditions, including ultrasonic wave and high temperature, are commonly used for improving the extraction efficiency, and various bioactive compounds prepared under different technologies always present varying degrees of activities [6-8]. Response surface methodology (RSM) can evaluate the impacts of processing parameters on response values by planning experiments and constructing models [9], and has been applied for optimizing the extraction processes of bioactive compounds [10]. Therefore, in this study, the S. miltiorrhiza glycoprotein (SMGP) was prepared under ultrasonic extraction, and the extraction conditions 
were optimized by RSM, which would be of benefit to its efficient utilization and use in industrial production.

Glycoproteins are a kind of proteins branched with moiety carbohydrate, which can be mainly found in plant cells. The subcellular localization (secreted or membraneassociated) and the extent of glycosylation present crucial effects on protein structure and relevant bioactivities [11]. In glycoproteins, carbohydrates are responsible for the selective interaction, and are involved in regulating many cellular processes [12]. The traditional extraction method for water-soluble bioactive compounds is generally water extraction, and then, alcohol solution is employed for the precipitation [13]. As is known, S. miltiorrhiza was usually used as the main component of medicinal liquor (ethanol volume fraction of $50 \sim 60 \%$ ) in China, and the ingredients prepared by traditional methods might present great differences with the bioactive substances dissolved in medicinal liquor [14]. Therefore, the bioactive glycoprotein from $S$. miltiorrhiza $60 \%$ was extracted using ethyl alcohol solution as the solvent in this study, aiming to provide a data foundation for the further application of medicinal liquor containing $S$. miltiorrhiza.

Immune responses, including immune defense, regulation, and surveillance, in vivo demonstrate important roles in protecting humans from various diseases [15,16]. As reported, multiple immune cells and their secretions can exert defensive and protective effects on body through efficaciously eliminating foreign pathogens [17,18]. Reactive oxygen species (ROS) can maintain the balance of the immune system, whereas the overproduction can damage the deoxyribonucleic acid and proteins of cells, which induces the incidence of various diseases, including immunosuppression, inflammatory, cardiovascular diseases, and cancer $[19,20]$. As reported, the number of immunocompromised patients has steadily increased in recent years, and quality-of-life has been severely affected [21]. Therefore, the development of novel bioactive compounds on immunization and antioxidant level improvement of the body is urgent. Cyclophosphamide (CTX) treatment can reduce the antioxidant ability, promote lipid peroxidation, and induce the immunosuppression of animals in vivo, and has been widely applied for constructing immune-deficient mice models [22]. Thus, in this study, the immunosuppressed mice model via CTX induction was established for the antioxidant and immunoregulation activity evaluation of SMGP.

In the present study, the glycoprotein (SMGP) was firstly isolated from the root powder of S. miltiorrhiza using $60 \%$ ethanol solution as the solvent, and the optimal extraction conditions were determined by RSM. Subsequently, the preliminary structural characteristics were identified via analyzing the molecular weight and chemical components, and then, the antioxidant and immunoregulation activities of SMGP in vivo were further evaluated through establishing a CTX-induced immune-deficient mice model. These results can provide a new idea for water-soluble active substance extraction, and can promote the practical applications of SMGP as an edible functional compound in the food industry, which could also help to improve the nutritional values of medicinal liquor containing S. miltiorrhiza.

\section{Materials and Methods}

\subsection{Materials and Regents}

The dried S. miltiorrhiza were provided by Tianjin Taijin Technology Co., Ltd. (Tianjin, China). The antioxidant capacity assay kits (ABTS, $\mathrm{DPPH}, \mathrm{OH}^{-}, \mathrm{O}_{2}^{-}$), antioxidant enzyme activities detection kits (SOD and GSH-PX), malondialdehyde (MDA) assay kit, immunoglobulin $\mathrm{G}$ assay kit, immunoglobulin $\mathrm{M}$ assay kit, and cytokine detection kits (TNF- $\alpha$, IFN- $\gamma$, IL-2, IL-4) were bought from Nanjing Jiancheng Bioengineering Institute (Nanjing, China), All of the other regents were of analytical grade.

\subsection{Preparation of SMGP}

The dried root powder of S. miltiorrhiza was extracted using $60 \%$ ethanol solution in an airtight container under ultrasonic assistance (Ultrasonic Cell Crusher JY92-IIDN from Ningbo Scientz Biotechnology Co., Ltd.) (Ningbo, China). Subsequently, the supernatant 
was obtained and concentrated, and the final ethanol volume of $80 \%$ was employed for the substances' precipitation. Then, these sediments were dissolved in distilled water, and purified through a water dialysis method (MWCO of 100,000 Da, dialysis time of $48 \mathrm{~h}$ ). Finally, the SMGP was obtained after lyophilization. The yield of SMGP was calculated as Formula (1):

Yield of SMGP $(\%)=($ SMGP weights $/$ S. miltiorrhiza roots powder weights $) \times 100$

\subsection{Optimization of SMGP Extraction Process}

The effects of four factors, including ultrasonic power $(A: 150,200,250 \mathrm{~W})$, ultrasonic time $(B: 1.5,2.0,2.5 \mathrm{~h})$, liquid/solid ratio $(C: 15,20,25 \mathrm{~mL} / \mathrm{g})$, and extraction temperature (D: $\left.50,60,70{ }^{\circ} \mathrm{C}\right)$, on SMGP extraction were evaluated by Box-Behnken design (BBD). These twenty-nine combinations at three levels were executed, and each combination was determined in triplicate.

\subsection{Chemical Components Determination of SMGP}

The phenol/sulfuric acid method [23], Coomassie brilliant blue method [24], and carbazole/sulfuric method [25] were used to detect the polysaccharide, protein, and uronic acid contents of SMGP, respectively.

\subsection{Ultraviolet Scanning and Molecular Weight Detection of SMGP}

The chemical constitution of SMGP was also confirmed by a 2500PC UV-Vis spectrophotometer (Shimadzu, Japan) through the ultraviolet full wavelength (200 nm 600 nm).

The average molecular weight of SMGP was evaluated using high performance gel permeation chromatography (HPGPC) equipped with a TSK-gel G4000PWxL (7.8 mm × $300 \mathrm{~mm})$, according to a previous reported method [26], and T-series dextrans of T110, T70, T40, T10, and T3 were employed as standards.

\subsection{Monosaccharides and Amino Acids Compositions of SMGP}

The monosaccharide constituents of SMGP were determined using gas chromatography (GCMS7890B-7000C, Agilent, CA, America), equipped with an HP-5 column, according to previous method after slight modifications [27]. Six monosaccharides, including L-rhamnose, D-arabinose, D-xylose, D-mannose, D-glucose, and D-galactose, were employed as standards. The amino acid compositions of SMGP after acid hydrolysis (hydrochloric acid concentration of $8 \mathrm{~mol} / \mathrm{L}$, hydrolysis temperature of $114{ }^{\circ} \mathrm{C}$, hydrolysis time of $10 \mathrm{~h}$ ) were determined using an amino acid automatic analyzer (L-8900, Japan Hitachi Corp, Tokyo, Japan).

\subsection{Antioxidant Activity In Vitro}

The antioxidant properties of SMGP on ABTS, DPPH, $\mathrm{OH}^{-}$, and $\mathrm{O}_{2}{ }^{-}$free radicals were determined according to the instructions. The SMGP concentrations of $0.25,0.5,1,2$, and $3 \mathrm{mg} / \mathrm{mL}$ were chosen for scavenging effects evaluation, and the same concentrations of vitamin $\mathrm{C}(\mathrm{Vc})$ were used as positive control.

\subsection{Animal Experiments Design}

Fifty female Kunming mice (8 weeks) were purchased from SPF (Beijing) Biotechnology Co., Ltd. (Beijing, China) with a production license number of SYXK(Jing)2019-0010, and raised in the experimental animal room with a license number of SYXK(Jin)2018-0001 with relative humidity of $45 \sim 55 \%$ ), and a controllable temperature of $20 \sim 25{ }^{\circ} \mathrm{C}$. All animalrelated experiments were conducted in accordance with the principles of Laboratory Animal Care, and approved by the Local Ethics Committee for Animal Care and Use at Tianjin University of Science and Technology.

After an acclimatization of $7 \mathrm{~d}$, all mice were divided into five groups at random, with 10 mice per group: blank group, model group, and SMGP groups (50 mg/kg, $100 \mathrm{mg} / \mathrm{kg}$, 
and $150 \mathrm{mg} / \mathrm{kg}$ ). Firstly, the normal saline solution of $0.2 \mathrm{~mL}$ was employed for intragastrical administration in the blank and model groups every day; meanwhile, corresponding concentrations of SMGP were orally administrated in SMGP groups. After 7 days, these mice, except the blank group, were intra-peritoneally injected with cyclophosphamide (CTX, $30 \mathrm{mg} / \mathrm{kg}$ ) for $15 \mathrm{~d}$, and the gastric perfusions were simultaneously conducted. Subsequently, all mice were sacrificed, and their thymuses were collected and weighed, and the thymus indices were calculated as the ratios of the weights $(\mathrm{mg})$ to body weights $(\mathrm{g})$.

\subsection{Antioxidant Effects In Vivo}

The in vivo antioxidant activities of SMGP were evaluated via detecting antioxidant enzyme activities and MDA contents using the corresponding kits.

\subsection{Immune Cells Activities Detection}

The NK (natural killer) cells, splenic lymphocytes, and peritoneal macrophages activities of mice in each group were determined referring to previous method [26].

\subsection{Antibodies and Cytokines Determination}

The antibody (IgG, IgM) and cytokine (IL-2, IL-4, TNF- $\alpha$, and IFN- $\gamma$ ) expressions in sera were evaluated by the corresponding ELISA kits following the instructions.

\subsection{Statistical Analysis}

All values in this study were expressed as the mean \pm standard deviation (S.D.), and each experiment was detected in triplicate. The significance of between-group differences was determined by Student's $t$-test and one-way analysis of variance (ANOVA): the value of $p<0.05$ was deemed as significant.

\section{Results and Discussions}

\subsection{Optimization of SMGP Extraction}

The ultrasonic power of $200 \mathrm{~W}$, ultrasonic time of $2 \mathrm{~h}$, liquid/solid ratio of $20 \mathrm{~mL} / \mathrm{g}$, and extraction temperature of $60{ }^{\circ} \mathrm{C}$ were chosen as intermediate values in the BBD experiment. Table 1 shows the average actual/predicted SMGP yields, and the results demonstrate that the actual SMGP yields were close to the corresponding predicted values, suggesting a high-precision fitted model [10]. The final equation according to four coded factors is as following (2):

$$
\begin{aligned}
\text { Yields } & =1.61+0.10 \times A-0.06 \times B+0.05 \times C+0.14 \times D-0.02 \times A B \\
& +0.01 \times A C+0.09 \times A D-0.05 \times B C-0.07 \times B D+0.01 \times C D \\
& -0.16 \times A^{2}-0.18 \times B^{2}-0.23 \times C^{2}-0.20 \times D^{2}
\end{aligned}
$$

The multi-regression model ANOVA in BBD was employed to measure the interaction effects of these factors on SMGP yields, and the results are presented in Table 2. As displayed, the $F$ value of 39.34 and $p$ value of $<0.0001$ indicated a highly significant model. The $p$ value of lack of fit was 0.7268 , which also suggested a fitted model [28]. Besides, statistical indicators, including $R^{2}$, Adj $R^{2}$, Pred $R^{2}$, and CV values, were $0.9752,0.9504$, 0.8935 , and 3.18, respectively, and the difference of Pred $R^{2}$ and Adj $R^{2}$ was less than 0.2 (0.0569), indicating a good correlation between actual and predicted values [29]. The parameters, including $A, B, C, D, A D, B C, B D, A^{2}, B^{2}, C^{2}$, and $D^{2}$, exhibited remarkable differences $(p<0.05)$ to SMGP yields, which was a similar tendency observed in a previously reported paper [30]. 
Table 1. Actual and predicted SMGP yields.

\begin{tabular}{|c|c|c|c|c|c|c|}
\hline \multirow[b]{2}{*}{ Run } & \multirow{2}{*}{$\begin{array}{c}\text { A } \\
\text { Ultrasonic Power } \\
\text { W }\end{array}$} & \multirow{2}{*}{$\begin{array}{c}\text { B } \\
\text { Ultrasonic Time }\end{array}$} & \multirow{2}{*}{$\begin{array}{c}\text { C } \\
\text { Solid/Liquid Ratio } \\
\mathrm{mL} / \mathrm{g}\end{array}$} & \multirow{2}{*}{$\begin{array}{c}\mathrm{D} \\
\text { Extraction Temperature } \\
{ }^{\circ} \mathrm{C}\end{array}$} & \multicolumn{2}{|c|}{ Yields } \\
\hline & & & & & $\begin{array}{c}\text { Actual Value } \\
\%\end{array}$ & $\begin{array}{c}\text { Predicted Value } \\
\%\end{array}$ \\
\hline 1 & 150 & 1.5 & 20 & 60 & 1.17 & 1.18 \\
\hline 2 & 250 & 1.5 & 20 & 60 & 1.38 & 1.41 \\
\hline 3 & 150 & 2.5 & 20 & 60 & 1.2 & 1.19 \\
\hline 4 & 250 & 2.5 & 20 & 60 & 1.34 & 1.31 \\
\hline 5 & 200 & 2 & 15 & 50 & 1.08 & 1.06 \\
\hline 6 & 200 & 2 & 25 & 50 & 1.17 & 1.17 \\
\hline 7 & 200 & 2 & 15 & 70 & 1.18 & 1.15 \\
\hline 8 & 200 & 2 & 25 & 70 & 1.29 & 1.29 \\
\hline 9 & 150 & 2 & 20 & 50 & 1.2 & 1.22 \\
\hline 10 & 250 & 2 & 20 & 50 & 1.22 & 1.21 \\
\hline 11 & 150 & 2 & 20 & 70 & 1.08 & 1.14 \\
\hline 12 & 250 & 2 & 20 & 70 & 1.48 & 1.49 \\
\hline 13 & 200 & 1.5 & 15 & 60 & 1.09 & 1.1 \\
\hline 14 & 200 & 2.5 & 15 & 60 & 1.08 & 1.14 \\
\hline 15 & 200 & 1.5 & 25 & 60 & 1.39 & 1.33 \\
\hline 16 & 200 & 2.5 & 25 & 60 & 1.17 & 1.18 \\
\hline 17 & 150 & 2 & 15 & 60 & 1.07 & 1.06 \\
\hline 18 & 250 & 2 & 15 & 60 & 1.25 & 1.24 \\
\hline 19 & 150 & 2 & 25 & 60 & 1.14 & 1.17 \\
\hline 20 & 250 & 2 & 25 & 60 & 1.37 & 1.39 \\
\hline 21 & 200 & 1.5 & 20 & 50 & 1.12 & 1.13 \\
\hline 22 & 200 & 2.5 & 20 & 50 & 1.2 & 1.19 \\
\hline 23 & 200 & 1.5 & 20 & 70 & 1.38 & 1.38 \\
\hline 24 & 200 & 2.5 & 20 & 70 & 1.16 & 1.17 \\
\hline 25 & 200 & 2 & 20 & 60 & 1.59 & 1.61 \\
\hline 26 & 200 & 2 & 20 & 60 & 1.67 & 1.61 \\
\hline 27 & 200 & 2 & 20 & 60 & 1.64 & 1.61 \\
\hline 28 & 200 & 2 & 20 & 60 & 1.57 & 1.61 \\
\hline 29 & 200 & 2 & 20 & 60 & 1.56 & 1.61 \\
\hline
\end{tabular}

Table 2. Analysis of variance for quadratic model.

\begin{tabular}{lllllll}
\hline Sources & $\begin{array}{l}\text { Sum of } \\
\text { Squares }\end{array}$ & $\begin{array}{l}\text { Degree of } \\
\text { Freedom }\end{array}$ & $\begin{array}{l}\text { Mean } \\
\text { Square }\end{array}$ & $\begin{array}{l}\boldsymbol{F} \\
\text { Value }\end{array}$ & $\begin{array}{l}\boldsymbol{p} \text {-Value } \\
\text { Prob }>\boldsymbol{F}\end{array}$ & Significance \\
\hline Model & 0.92 & 14 & 0.066 & 39.34 & $<0.0001$ & Significant \\
$A$ & 0.12 & 1 & 0.12 & 70.08 & $<0.0001$ & 0.0187 \\
$B$ & 0.012 & 1 & 0.012 & 7.07 & $<0.0001$ \\
$C$ & 0.049 & 1 & 0.049 & 29.49 & 0.0009 \\
$D$ & 0.029 & 1 & 0.029 & 17.63 & 0.3973 \\
$A B$ & $1.27 \times 10^{-3}$ & 1 & $1.27 \times 10^{-3}$ & 0.76 & 0.5924 \\
$A C$ & $5.02 \times 10^{-4}$ & 1 & $5.02 \times 10^{-4}$ & 0.3 & 0.0005 \\
$A D$ & 0.033 & 1 & 0.033 & 19.81 & 0.0272 \\
$B C$ & 0.01 & 1 & 0.01 & 6.08 & 0.0029 \\
$B D$ & 0.022 & 1 & 0.022 & 12.96 & 0.8066 \\
$C D$ & $1.04 \times 10^{-4}$ & 1 & $1.04 \times 10^{-4}$ & 0.062 & $<0.0001$ \\
$A^{2}$ & 0.16 & 1 & 0.16 & 97.13 & $<0.0001$ \\
$B^{2}$ & 0.22 & 1 & 0.22 & 132.53 & $<0.0001$ \\
$C^{2}$ & 0.36 & 1 & 0.36 & 212.71 & $<.0001$ \\
$D^{2}$ & 0.26 & 1 & 0.26 & 152.64 & \\
Residual & 0.023 & 14 & $1.67 \times 10^{-3}$ & & 0.6792 \\
Lack of Fit & 0.015 & 10 & $1.52 \times 10^{-3}$ & 0.75 & \\
Pure Error & $8.17 \times 10^{-3}$ & 4 & $2.04 \times 10^{-3}$ & & \\
Cor Total & 0.94 & 28 & & Adj $R^{2}$ & 0.9504 & \\
$R^{2}$ & 0.9752 & C.V. \% & 3.18 & \\
Pred $R^{2}$ & 0.8935 & & & & \\
\hline
\end{tabular}




\subsection{Interactive Effects Analysis}

The two-dimensional (2D) and three-dimensional (3D) maps presenting the interaction effects between every two factors on SMGP yields are displayed in Figure 1. As presented, these response surface curves exhibited a maximum point in the experimental ranges, suggesting a reasonable factors' ranges selection. The elliptical/circular contour plots could reflect the significant/indistinctive interaction effects between these variables [31]. Therefore, Figure 1C-E,c-e exhibit more elliptical contour lines and steeper response surfaces than others, which demonstrates the significant interaction effects of ultrasonic power and extraction temperature, ultrasonic time and liquid/solid ratio, and ultrasonic time and extraction temperature on SMGP yields.

(A)
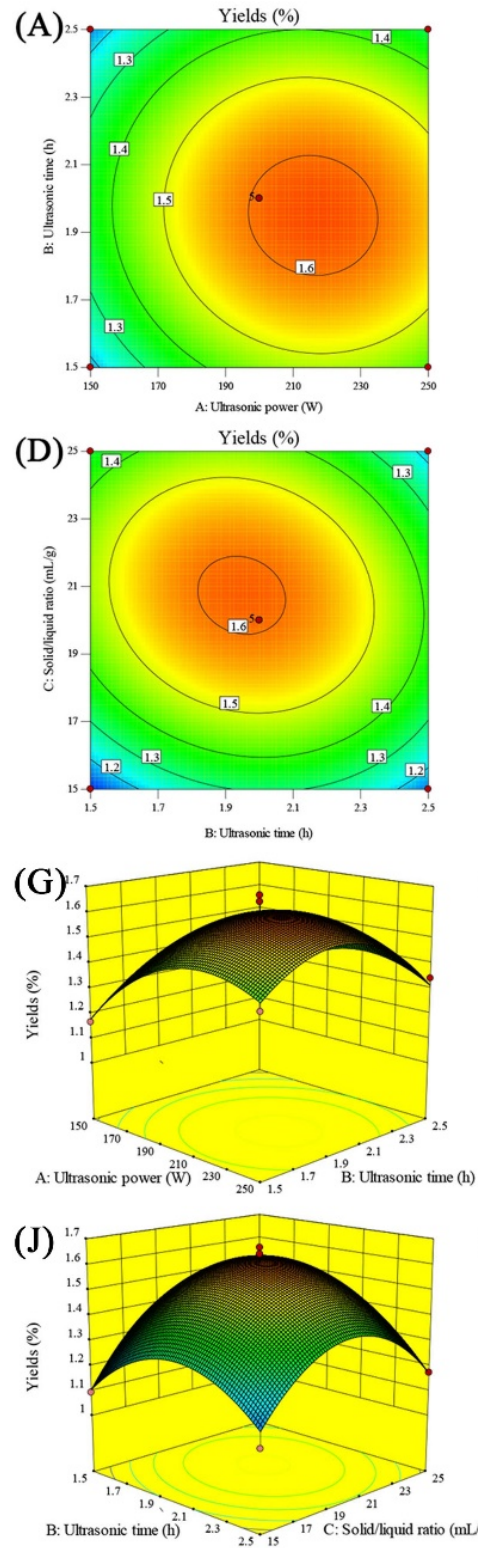
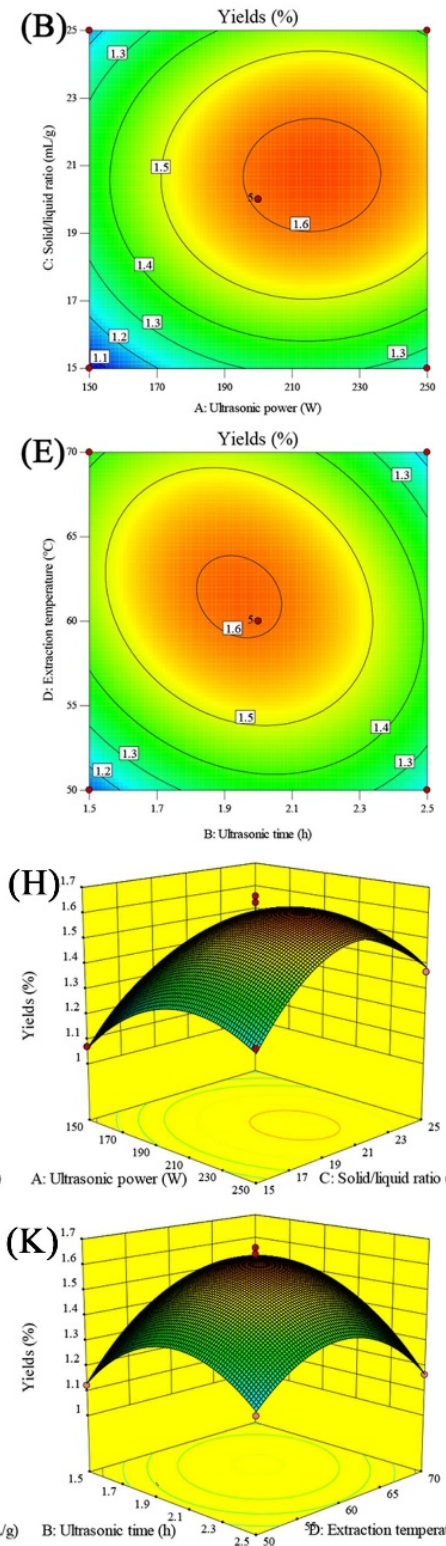
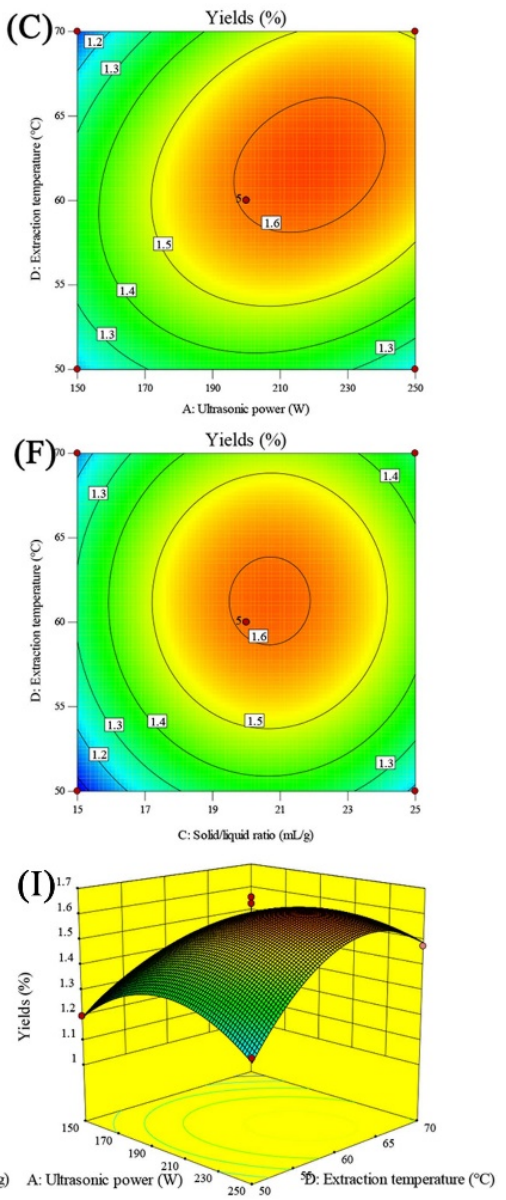

$(\mathrm{L})$

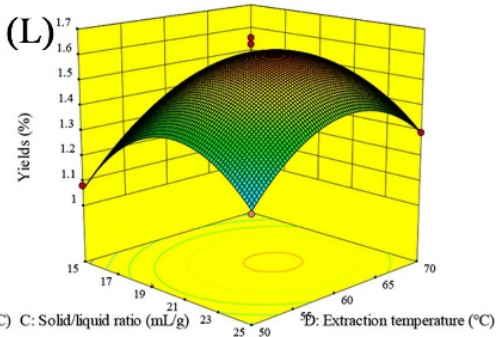

Figure 1. Two-dimensional and three-dimensional maps. (A,G): ultrasonic power and ultrasonic time; $(\mathbf{B}, \mathbf{H})$ : ultrasonic power and liquid/solid ratio; (C,I): ultrasonic power and extraction temperature; $(\mathbf{D}, \mathrm{J})$ : ultrasonic time and liquid/solid ratio; $(\mathbf{E}, \mathbf{K})$ : ultrasonic time and extraction temperature; $(\mathbf{F}, \mathbf{L})$ : liquid/solid ratio and extraction temperature.

\subsection{Optimized Conditions}

In Design-Expert software 10.0, the optimized conditions for maximum SMGP yields were calculated as follows: ultrasonic power of $220.023 \mathrm{~W}$, ultrasonic time of $1.9112 \mathrm{~h}$, 
liquid/solid ratio of $20.842 \mathrm{~mL} / \mathrm{g}$, extraction temperature of $62.519{ }^{\circ} \mathrm{C}$, and predicted SMGP yield of $1.640 \%$. However, these parameters were hard to be well-controlled for industrial production; therefore, the experimental parameters were embellished as follows: ultrasonic power of $220 \mathrm{~W}$, ultrasonic time of $2.0 \mathrm{~h}$, liquid/solid ratio of $20 \mathrm{~mL} / \mathrm{g}$, extraction temperature of $60{ }^{\circ} \mathrm{C}$, and SMGP yields of $1.63 \pm 0.04 \%$. Besides, in the preliminary experiment, the SMGP yields were $1.15 \pm 0.06 \%$ under the initial extraction conditions (ultrasonic power of $250 \mathrm{~W}$, ultrasonic time of $2.0 \mathrm{~h}$, liquid/solid ratio of $20 \mathrm{~mL} / \mathrm{g}$, extraction temperature of $70{ }^{\circ} \mathrm{C}$ ). These data indicated that RSM could effectively optimize the extraction parameters of SMGP, and could provide mathematical models and intuitive graphs for preferable evaluation.

\subsection{Chemical Composition, UV, and HPGPC Analysis of SMGP}

The chemical compositions of SMGP were determined using the previously mentioned methods, and the results exhibited that the average contents of polysaccharide, protein, and uronic acid in SMGP were 20.62\%, 76.96\%, and 1.16\%, respectively, indicating the SMGP belonged to a kind of glycoprotein that employed protein as the backbone, and branched with the oligosaccharide chain.

Figure 2A displays an obvious absorption peak at $280 \mathrm{~nm}$, indicating that SMGP contained large quantities of amino acids, which was consistent with the protein content determination result. As presented in Figure 2B, a uniformly distributed peak at $7.582 \mathrm{~min}$ was observed, suggesting that the average molecular weight of SMGP was $1.55 \times 10^{5} \mathrm{Da}$ based on the standard curve $\left(y=18.833-1.7988 x, r^{2}=0.9991\right.$, where $y$ represents the natural logarithm of molecular weight, and $x$ represents the corresponding retention time).

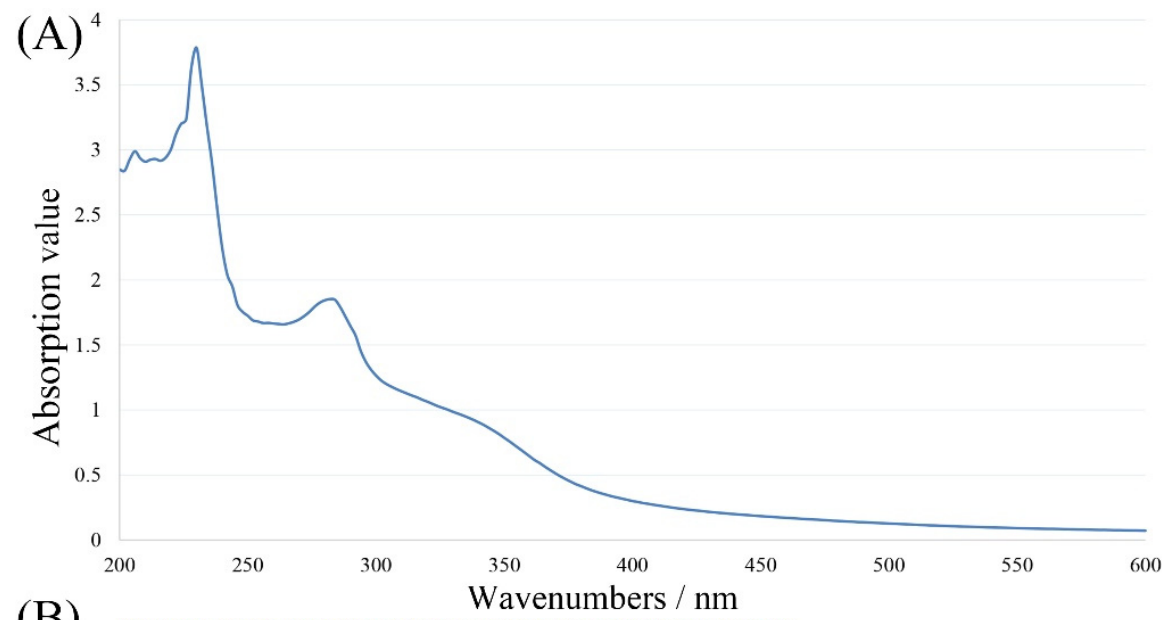

(B) RID1 A, Refractive Index Signal (20201226-YJIYUJUAN 2020-12-26 10-05-501008-P1-A8-J6T.D)

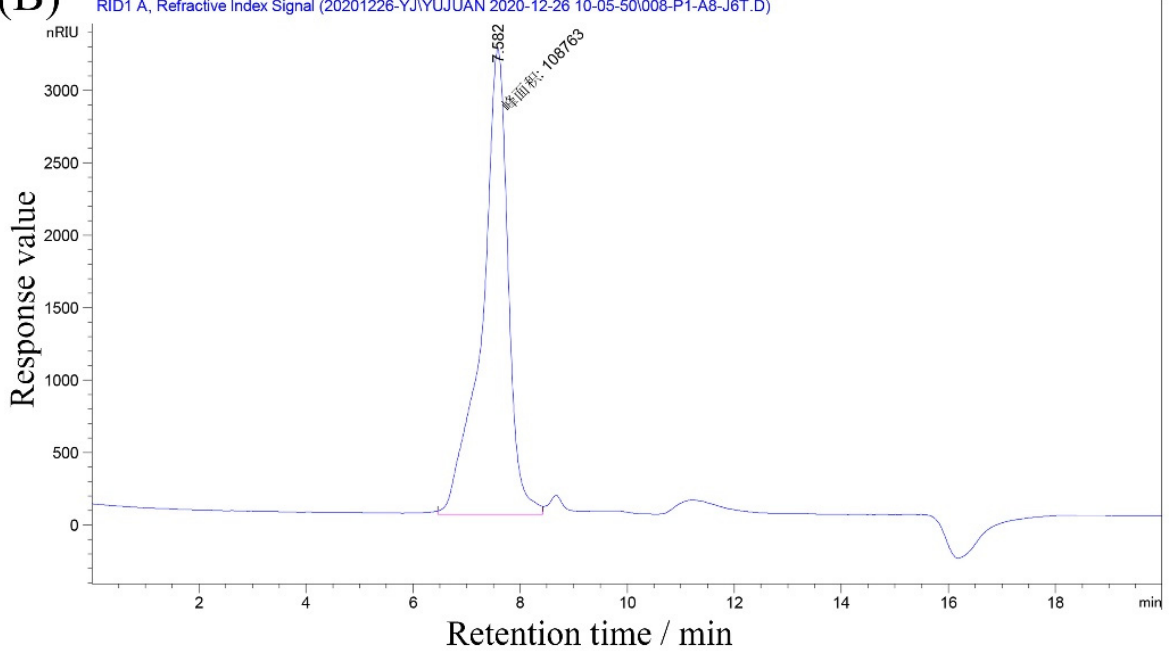

Figure 2. UV (A) and HPGPC (B) spectra of SMGP. 


\subsection{Monosaccharide Compositions of SMGP}

The monosaccharide compositions of SMGP were evaluated by GC, and the results are displayed in Figure 3. As presented, SMGP was primarily comprised of rhamnose (Rha), arabinose (Ara), mannose (Man), glucose (Glc), and galactose (Gal) in a molar ratio of 0.53:0.52:1.00:0.53:0.74.

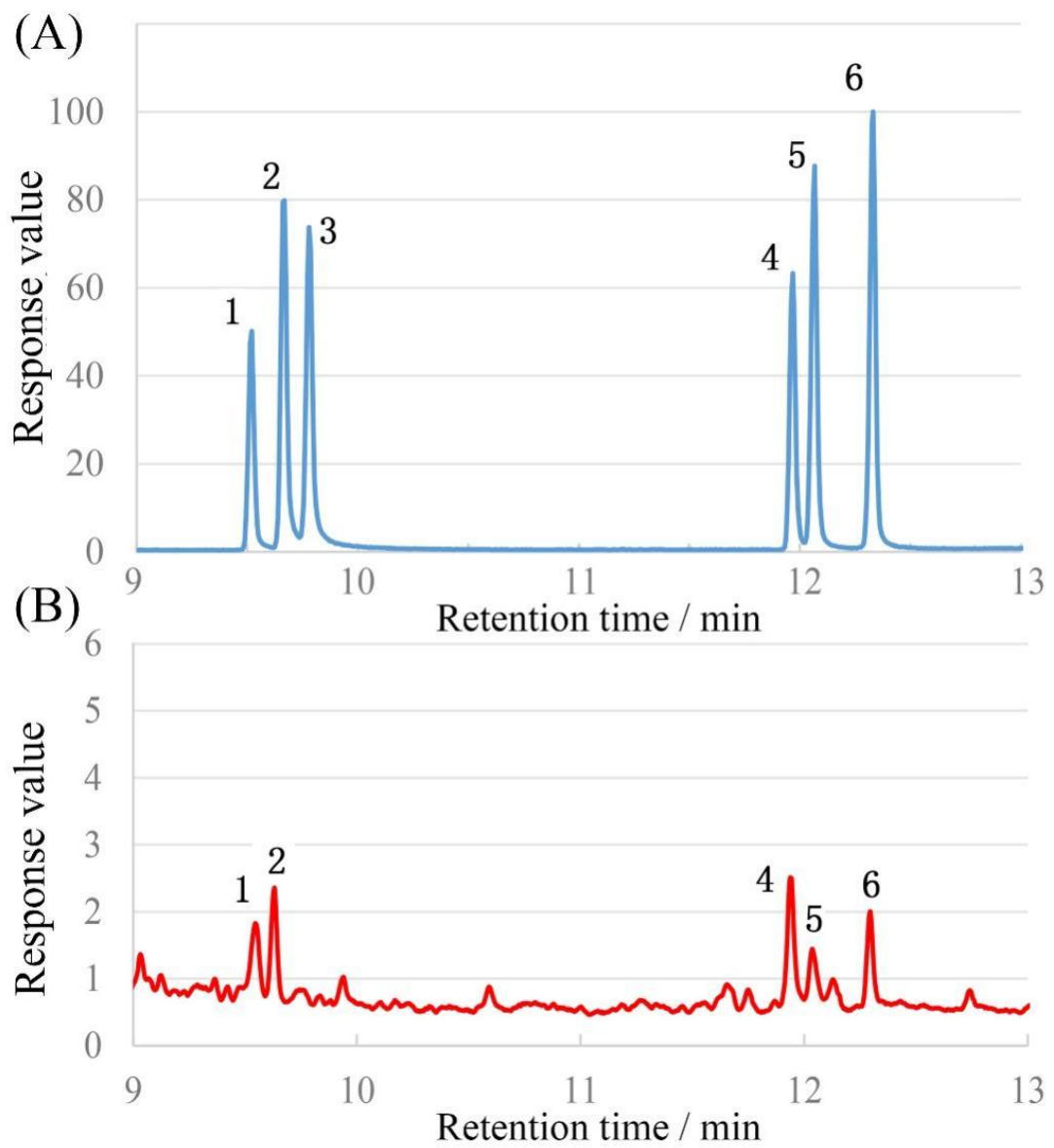

Figure 3. Monosaccharide composition results of SMGP. (A), monosaccharide standards; (B), SMGP derivatives. Note: 1-L-rhamnose; 2-D-arabinose; 3-D-xylose; 4-D-mannose; 5-D-glucose; 6-D-galactose.

\subsection{Types and Contents of Amino Acids in SMGP}

The amino acid types and contents of SMGP were determined after acid hydrolysis, and the result is shown in Table 3. As presented, there were 16 kinds of amino acids detected in SMGP, and the glutamic acid, valine, aspartic acid, and phenylalanine contents were higher than $10 \%$, which are the typical plant-derived amino acids.

Table 3. Types and contents of amino acids in SMGP.

\begin{tabular}{cccccc}
\hline Amino Acids & Abbreviations & $\begin{array}{c}\text { Contents } \\
\mathbf{( \% )}\end{array}$ & Amino Acids & Abbreviations & $\begin{array}{c}\text { Contents } \\
\mathbf{( \% )}\end{array}$ \\
\hline Glutamic acid & Glu & $12.97 \%$ & Leucine & Leu & $5.08 \%$ \\
Valine & Val & $12.03 \%$ & Isoleucine & Ile & $4.89 \%$ \\
Aspartic acid & Asp & $10.71 \%$ & Glycine & Gly & $4.32 \%$ \\
Phenylalanine & Phe & $10.34 \%$ & Alanine & Arg & $3.95 \%$ \\
Threonine & Thr & $8.83 \%$ & Lysine & Lys & $3.01 \%$ \\
Serine & Ser & $6.77 \%$ & Histidine & His & $2.63 \%$ \\
Proline & Pro & $6.20 \%$ & Methionine & Met & $1.50 \%$ \\
Tyrosine & Tyr & $5.64 \%$ & & & \\
\hline
\end{tabular}




\subsection{Antioxidant Activities In Vitro}

Excessive production and accumulation of ROS can induce oxidative stress and various diseases, and severely threaten a human's health [32]. As reported, the free radicals, including $\mathrm{O}_{2}{ }^{-}, \mathrm{OH}^{-}, \mathrm{ABTS}$, and $\mathrm{DPPH}$, have been widely used to evaluate the in vitro antioxidant activities of various bioactive substances. The $\mathrm{OH}^{-}$and $\mathrm{O}_{2}^{-}$free radicals are mainly generated from mitochondrial oxidative metabolism, and are involved in regulating cellular growth and development [33]. DPPH and ABTS free radicals are stable free radicals, and have been commonly employed as substrates to evaluate the scavenging capacities of multiple compounds in vitro [34,35].

The scavenging effects of SMGP $(0.25,0.5,1.0,2.0,3.0 \mathrm{mg} / \mathrm{mL})$ on $\mathrm{O}_{2}{ }^{-}, \mathrm{OH}^{-}, \mathrm{ABTS}$, and DPPH free radicals were evaluated, and the results are shown in Figure 4 . The scavenging effects of SMGP on $\mathrm{O}_{2}{ }^{-}, \mathrm{OH}^{-}, \mathrm{ABTS}$, and DPPH radicals were remarkably improved with the increased SMGP concentrations (from 0.25 to $3.0 \mathrm{mg} / \mathrm{mL}$ ), and the maximum antioxidant capacities on $\mathrm{O}_{2}{ }^{-}, \mathrm{OH}^{-}, \mathrm{ABTS}$, and $\mathrm{DPPH}$ free radicals reached $148.95 \pm 9.98 \mathrm{U} / \mathrm{L}, 277.78 \pm 13.89 \mathrm{U} / \mathrm{mL}, 89.16 \pm 3.34 \%$, and $86.82 \pm 3.29 \%$, respectively, which was significantly higher than the in vitro antioxidant effects exerted by reported individual polysaccharides or proteins $[36,37]$. These results demonstrated that SMGP could exhibit stronger scavenging effects on free radicals, which was consistent with the antioxidant effects of a Fupenzi glycoprotein [38].
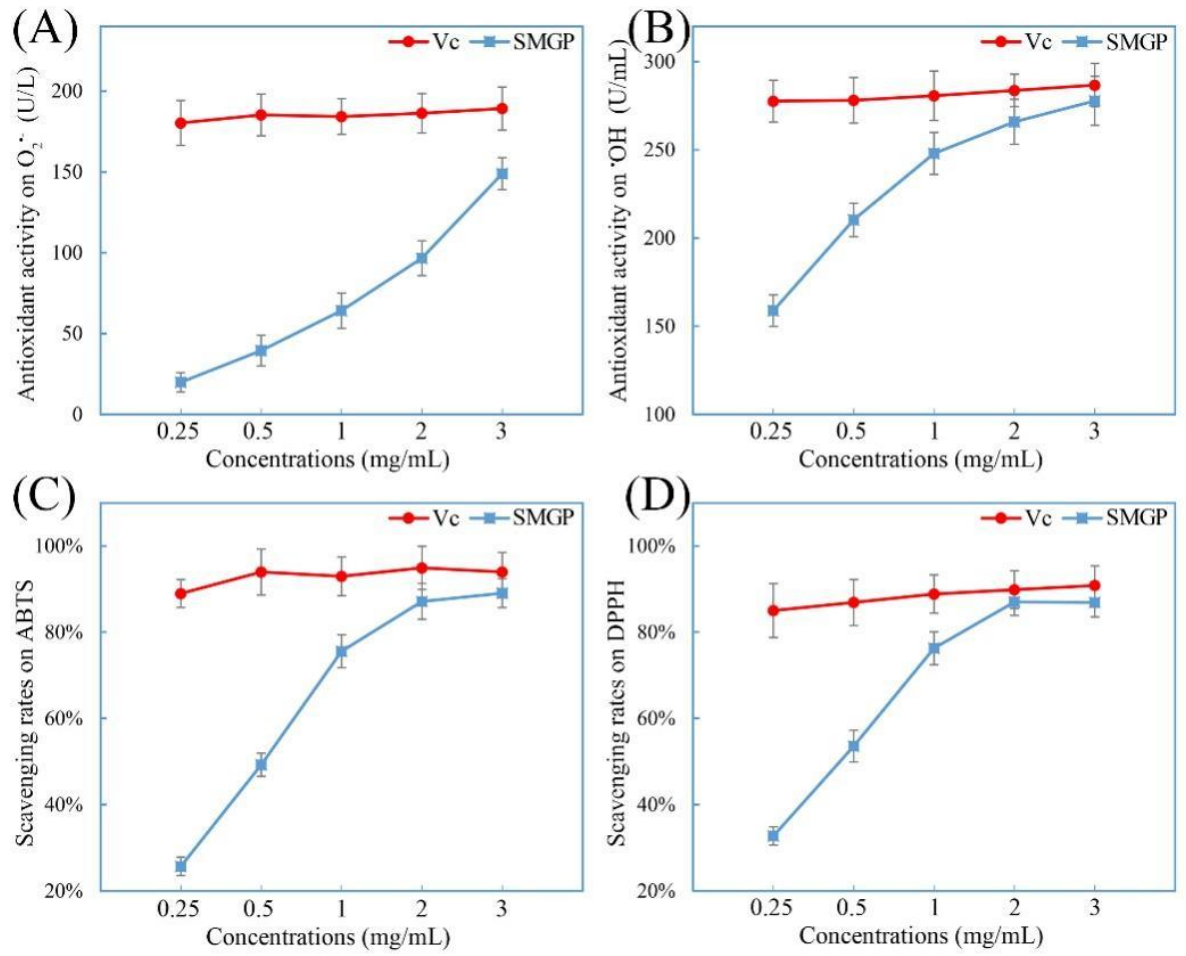

Figure 4. Free radical scavenging capacities ((A) $\mathrm{O}_{2}{ }^{-} ;(\mathbf{B}) \mathrm{OH}^{-} ;(\mathbf{C})$ ABTS; (D) DPPH) of SMGP.

\subsection{Antioxidant Activities In Vivo}

$\mathrm{SOD}$ is the only enzyme that can scavenge $\mathrm{O}_{2}{ }^{-}$free radicals specifically, and SOD activity enhancement could be an effective method to improve antioxidant effects, and relieve oxidative stress [39]. GSH-Px can reduce $\mathrm{H}_{2} \mathrm{O}_{2}$ to $\mathrm{H}_{2} \mathrm{O}$ in cytosol, and this activity has been widely used to reflect the in vivo antioxidant levels [40]. The MDA can damage the structure of proteins and DNA as the final breakdown product in the lipid peroxidation process, and the concentration has been used as a positive indicator to reflect oxidative stress [41]. These antioxidant enzymes activities and MDA contents in sera were determined, and the results are displayed in Table 4. 
Table 4. Antioxidant enzyme activities and MDA contents.

\begin{tabular}{|c|c|c|c|c|c|}
\hline \multicolumn{2}{|c|}{ Groups } & $\begin{array}{c}\text { SOD } \\
\text { (Unit) }\end{array}$ & $\begin{array}{c}\text { GSH-Px } \\
\text { (Unit) }\end{array}$ & $\begin{array}{c}\text { MDA } \\
\text { (nmol) }\end{array}$ & $\begin{array}{c}\text { T-AOC } \\
\text { (Unit) }\end{array}$ \\
\hline \multicolumn{2}{|c|}{ Blank group } & $148.53 \pm 8.35$ & $355.47 \pm 24.37$ & $4.39 \pm 0.37$ & $34.24 \pm 2.15$ \\
\hline \multicolumn{2}{|c|}{ Model group } & $124.26 \pm 9.26^{\mathrm{a}}$ & $298.38 \pm 18.42^{a}$ & $6.69 \pm 0.47^{a}$ & $33.86 \pm 1.87$ \\
\hline \multirow{3}{*}{ SMGP groups } & $50 \mathrm{mg} / \mathrm{kg}$ & $139.48 \pm 7.18^{b}$ & $325.56 \pm 19.49^{b}$ & $5.63 \pm 0.49^{b}$ & $35.02 \pm 1.49$ \\
\hline & $100 \mathrm{mg} / \mathrm{kg}$ & $153.37 \pm 9.05^{b}$ & $342.48 \pm 21.47^{b}$ & $5.03 \pm 0.32^{b}$ & $33.84 \pm 2.16$ \\
\hline & $150 \mathrm{mg} / \mathrm{kg}$ & $166.58 \pm 8.79^{b}$ & $367.16 \pm 22.21^{b}$ & $4.17 \pm 0.33^{b}$ & $34.93 \pm 1.24$ \\
\hline
\end{tabular}

Note: ${ }^{\mathrm{a}}, p<0.05$ compared with blank group; ${ }^{\mathrm{b}} p<0.05$ compared with model group.

As demonstrated, the SOD and GSH-Px activities in sera of CTX-treated mice were obviously reduced compared with the blank group, whereas the MDA contents were significantly increased, indicating that CTX could dramatically decrease the antioxidant effects in mice. However, compared with the model group, the antioxidant enzyme activities were significantly enhanced after SMGP treatments, whereas the MDA contents were obviously reduced dose-dependently, which suggested that SMGP could observably improve the antioxidant activities of mice even after CTX treatment. However, the T-AOC values in mice sera presented no significant difference among these groups, suggesting strong self-regulating capacities. As reported, Ganoderma lucidum polysaccharides can enhance antioxidant activities in ovarian cancer rats [42]. Allium mongolicum Regel polysaccharide can enhance sera's SOD and GSHPx activities, and decrease the contents of MDA [43,44]. In this study, the SMGP exhibited a strong enhancement of the enzyme activities in CTX-treated mice as a kind of natural edible glycoprotein, which resulted in the decrease of MDA contents in sera.

\subsection{Thymus Indices and Immune Cell Activities}

In this study, the determination results of the thymus weights/indices and immune cell activities are displayed in Figure 5. The thymus weights/indices of the model group were obviously reduced compared with that of the blank group, suggesting that CTX induced oxidative stress, and caused thymus atrophy. However, the thymus weights/indices of SMGP groups were significantly increased compared with that of the model group dose-dependently, indicating the antioxidant activities and thymus protection of SMGP in CTX-treated mice.

Figure $5 \mathrm{C}-\mathrm{F}$ demonstrates the immune cell activity determination results. As shown, the immune cell activities of the model group were all observably decreased compared with that of the blank group, suggesting the immunosuppressive effects of CTX injection. However, after different concentrations of SMGP treatments, the cell activities were all dose-dependently enhanced, which demonstrated that SMGP could significantly enhance the immune cell activities in mice, even after CTX treatment.

\subsection{Antibody Levels and Cytokine Expressions In Sera}

The thymus promotes the development and differentiation of $\mathrm{T}$ cells, and plays a crucial role in protecting the body against immunocompromised-induced diseases, which have been employed as preliminary evaluation indicators in relevant animal experiments [26]. IL-2 and IL-4 are secreted by immune cells, and enhance T cell and NK cell activities $[45,46]$. TNF- $\alpha$ and IFN- $\gamma$ exhibit direct cytotoxicity, and can also activate lymphocytes, macrophages, and NK cells to enhance immune capacity $[47,48]$.

The expression level results of antibodies (A, IgG; B, IgM) and cytokines (C, IL-2; D, IL$4 ; \mathrm{E}, \mathrm{TNF}-\alpha ; \mathrm{F}, \mathrm{IFN}-\gamma)$ of each group are presented in Figure 6. As displayed, the antibody expression levels, including IgG and IgM, of mice after CTX treatment were dramatically reduced compared with that of the blank group, suggesting that CTX significantly inhibited humoral immune activity (mediated by B cells). However, SMGP treatments effectively improved the antibody secretions in a dose-dependent manner compared with the model group, indicating the immune enhancement of SMGP on B cells. Besides, the expressions of IL-2, IL-4, TNF- $\alpha$, and IFN- $\gamma$ of the model group were all significantly reduced compared with that of the blank group, indicating that CTX treatment could also severely suppress the 
immunoregulation capability in vivo. However, SMGP remarkably improved the cytokine expressions, with a dosage association, which would be of benefit to the corresponding immune cell activation for better exerting relevant immune responses.
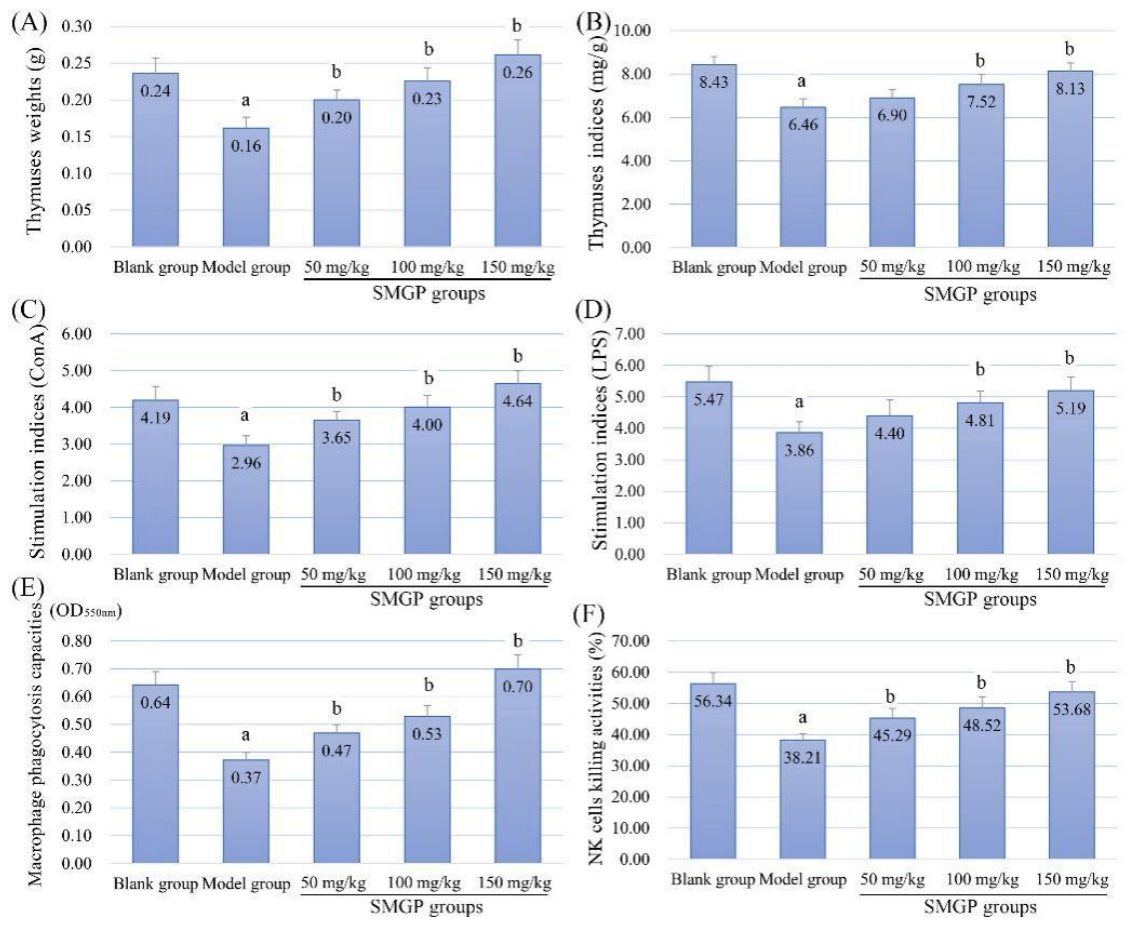

Figure 5. Thymus indicators ((A) weights; (B) indices) and immune cell activities ((C) T lymphocytes proliferation ability; (D) B lymphocytes proliferation ability; (E) macrophages phagocytosis capacity; (F) NK cell killing activities) of mice. Note: a, $p<0.05$ compared with blank group; $\mathrm{b}, p<0.05$ compared with model group.
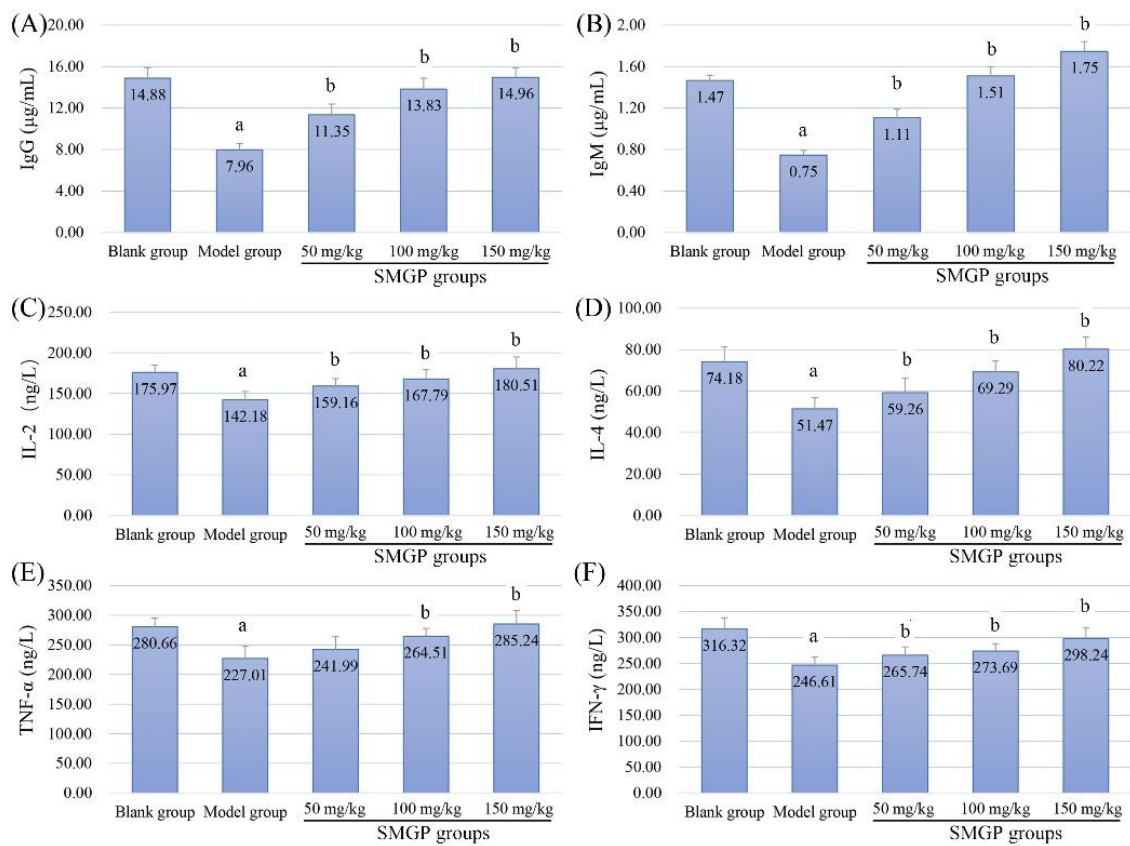

Figure 6. Antibody levels ((A) IgG; (B) IgM) and cytokines expressions ((C) IL-2; (D) IL-4; (E) TNF- $\alpha$; (F) IFN- $\gamma$ ) of mice in each group. Note: $\mathrm{a}, p<0.05$ compared with blank group; $\mathrm{b}, p<0.05$ compared with model group. 
As reported, Ganoderma lucidum polysaccharides could enhance the activities of multiple immune cells, and improve the expressions levels of IL-2, IFN- $\gamma$ [49]. Besides, the $S$. miltiorrhiza polysaccharides have also exhibited enhancements on various leukocyte subset activities and cytokine expressions in animals [10,50]. However, the glycoprotein from $S$. miltiorrhiza and related bioactivities have rarely been researched. In this study, the SMGP was isolated by ethanol-extraction technology, and improved the immune-associated cytokine/antibody expressions in CTX-treated mice, thereby effectively enhancing the corresponding immune cell activities.

\section{Conclusions}

The optimal extraction parameters for SMGP were identified as follows: ultrasonic power of $220 \mathrm{~W}$, ultrasonic time of $2.0 \mathrm{~h}$, liquid/solid ratio of $20 \mathrm{~mL} / \mathrm{g}$, extraction temperature of $60{ }^{\circ} \mathrm{C}$, and yields of $1.63 \pm 0.04 \%$. The prepared SMGP was mainly composed of protein and polysaccharide (contents of $76.96 \%$ and $20.62 \%$, respectively), with the average molecular weight of $1.55 \times 10^{5} \mathrm{Da}$. Moreover, SMGP presented superior scavenging effects on free radicals in vitro, and exhibited strong antioxidant activities and immunological enhancement on various immune cells in CTX-treated mice. These data could provide a new extraction technology for water-soluble active substances, and the theoretical foundation for the practical application of SMGP as an antioxidant or immunopotentiator in the food industry.

Author Contributions: Conceptualization, Data curation, Writing—review \& editing, H.-Y.J.; Data curation, Formal analysis, K.-Y.D.; Data curation, Methodology, C.L.; Writing-original draft, J.Y.; Supervision, Funding acquisition, X.-Y.J.; Resources, A.-J.L. All authors have read and agreed to the published version of the manuscript.

Funding: This study was funded by the Key Laboratory of Storage of Agricultural Products, Ministry of Agriculture and Rural Affairs (No. of Kf2021007).

Institutional Review Board Statement: Not applicable.

Informed Consent Statement: Not applicable.

Data Availability Statement: Data is contained within the article.

Conflicts of Interest: The authors declare that they have no known competing financial interest or personal relationships that could have appeared to influence the work reported in this paper.

\section{References}

1. Cai, X.; Zhang, H.; Li, T. Multi-target pharmacological mechanisms of Salvia miltiorrhiza against oral submucous fibrosis: A network pharmacology approach. Arch. Oral Biol. 2021, 126, 105131. [CrossRef] [PubMed]

2. $\quad$ Lin, Y.-S.; Peng, W.-H.; Shih, M.-F.; Cherng, J.-Y. Anxiolytic effect of an extract of Salvia miltiorrhiza Bunge (Danshen) in mice. J. Ethnopharmacol. 2020, 264, 113285. [CrossRef]

3. Chen, X.; Guo, J.; Bao, J.; Lu, J.; Wang, Y. The Anticancer Properties of Salvia Miltiorrhiza Bunge (Danshen): A Systematic Review. Med. Res. Rev. 2013, 34, 768-794. [CrossRef] [PubMed]

4. Zhou, L.; Zuo, Z.; Chow, M.S.S. Danshen: An Overview of Its Chemistry, Pharmacology, Pharmacokinetics, and Clinical Use. J. Clin. Pharmacol. 2005, 45, 1345-1359. [CrossRef] [PubMed]

5. Ma, S.; Zhang, D.; Lou, H.; Sun, L.; Ji, J. Evaluation of the anti-inflammatory activities of tanshinones isolated from Salvia miltiorrhiza var. alba roots in THP-1 macrophages. J. Ethnopharmacol. 2016, 188, 193-199. [CrossRef]

6. Olawuyi, I.; Kim, S.R.; Hahn, D.; Lee, W.Y. Influences of combined enzyme-ultrasonic extraction on the physicochemical characteristics and properties of okra polysaccharides. Food Hydrocoll. 2019, 100, 105396. [CrossRef]

7. Park, J.J.; Lee, W.Y. Anti-glycation effect of Ecklonia cava polysaccharides extracted by combined ultrasound and enzyme-assisted extraction. Int. J. Biol. Macromol. 2021, 180, 684-691. [CrossRef] [PubMed]

8. Hashemifesharaki, R.; Xanthakis, E.; Altintas, Z.; Guo, Y.; Gharibzahedi, S.M.T. Microwave-assisted extraction of polysaccharides from the marshmallow roots: Optimization, purification, structure, and bioactivity. Carbohydr. Polym. 2020, 240, 116301. [CrossRef]

9. Jha, A.K.; Sit, N. Comparison of response surface methodology (RSM) and artificial neural network (ANN) modelling for supercritical fluid extraction of phytochemicals from Terminalia chebula pulp and optimization using RSM coupled with desirability function (DF) and genetic algorithm (GA) and ANN with GA. Ind. Crop. Prod. 2021, 170, 113769. [CrossRef] 
10. Ji, H.-Y.; Liu, C.; Dai, K.-Y.; Yu, J.; Liu, A.-J.; Chen, Y.-F. The extraction, structure, and immunomodulation activities in vivo of polysaccharides from Salvia miltiorrhiza. Ind. Crop. Prod. 2021, 173, 114085. [CrossRef]

11. Lara-Mondragón, C.M.; MacAlister, C.A. Partial purification and immunodetection of cell surface glycoproteins from plants. Methods Cell Biol. 2020, 160, 215-234. [CrossRef] [PubMed]

12. Unione, L.; Ardá, A.; Jiménez-Barbero, J.; Millet, O. NMR of glycoproteins: Profiling, structure, conformation and interactions. Curr. Opin. Struct. Biol. 2020, 68, 9-17. [CrossRef]

13. Seedevi, P.; Moovendhan, M.; Sudharsan, S.; Sivasankar, P.; Sivakumar, L.; Vairamani, S.; Shanmugam, A. Isolation and chemical characteristics of rhamnose enriched polysaccharide from Grateloupia lithophila. Carbohydr. Polym. 2018, 195, 486-494. [CrossRef] [PubMed]

14. Ji, H.-Y.; Dai, K.-Y.; Liu, C.; Yu, J.; Liu, A.-J.; Chen, Y.-F. The ethanol-extracted polysaccharide from Cynanchum paniculatum: Optimization, structure, antioxidant and antitumor effects. Ind. Crop. Prod. 2021, 175, 114243. [CrossRef]

15. Braun, D.A.; Street, K.; Burke, K.P.; Cookmeyer, D.L.; Denize, T.; Pedersen, C.B.; Gohil, S.H.; Schindler, N.; Pomerance, L.; Hirsch, L.; et al. Progressive immune dysfunction with advancing disease stage in renal cell carcinoma. Cancer Cell 2021, 39, 632-648.e8. [CrossRef] [PubMed]

16. Kirsch-Volders, M.; Bolognesi, C.; Ceppi, M.; Bruzzone, M.; Fenech, M. Micronuclei, inflammation and auto-immune disease Mutat. Res. Mutat. Res. 2020, 786, 108335. [CrossRef]

17. de Moraes-Pinto, M.I.; Suano-Souza, F.; Aranda, C.S. Immune system: Development and acquisition of immunological competence. J. de Pediatr. 2020, 97, S59-S66. [CrossRef]

18. Estevez, J.; Chen, V.; Podlaha, O.; Li, B.; Le, A.; Vutien, P.; Chang, E.T.; Rosenberg-Hasson, Y.; Jiang, Z.; Pflanz, S.; et al. Differential Serum Cytokine Profiles in Patients with Chronic Hepatitis B, C, and Hepatocellular Carcinoma. Sci. Rep. 2017, 7, 1-11. [CrossRef]

19. Lorenzo, J.M.; Munekata, P.E.; Gómez, B.; Barba, F.J.; Mora, L.; Pérez-Santaescolástica, C.; Toldrá, F. Bioactive peptides as natural antioxidants in food products-A review. Trends Food Sci. Technol. 2018, 79, 136-147. [CrossRef]

20. Ngo, D.-H.; Vo, T.-S.; Wijesekara, I.; Kim, S.-K. Biological activities and potential health benefits of bioactive peptides derived from marine organisms. Int. J. Biol. Macromol. 2012, 51, 378-383. [CrossRef]

21. Lemiale, V.; Yvin, E.; Kouatchet, A.; Mokart, D.; Demoule, A.; Dumas, G. Oxygenation strategy during acute respiratory failure in immunocompromised patients. J. Intensiv. Med. 2021, 1, 81-89. [CrossRef]

22. Ebokaiwe, A.P.; Obasi, D.O.; Njoku, R.C.C.; Osawe, S.; Olusanya, O.; Kalu, W.O. Cyclophosphamide instigated hepaticrenal oxidative/inflammatory stress aggravates immunosuppressive indoleamine 2,3-dioxygenase in male rats: Abatement by quercetin. Toxicology 2021, 464, 153027. [CrossRef] [PubMed]

23. DuBois, M.; Gilles, K.A.; Hamilton, J.K.; Rebers, P.A.; Smith, F. Colorimetric method for determination of sugars and related substances. Anal. Chem. 1956, 28, 350-356. [CrossRef]

24. Barbosa, H.; Slater, N.K.; Marcos, J.C. Protein quantification in the presence of poly(ethylene glycol) and dextran using the Bradford method. Anal. Biochem. 2009, 395, 108-110. [CrossRef] [PubMed]

25. Bitter, T.; Muir, H.M. A modified uronic acid carbazole reaction. Anal. Biochem. 1962, 4, 330-334. [CrossRef]

26. Yu, J.; Ji, H.-Y.; Liu, C.; Liu, A.-J. The structural characteristics of an acid-soluble polysaccharide from Grifola frondosa and its antitumor effects on H22-bearing mice. Int. J. Biol. Macromol. 2020, 158, 1288-1298. [CrossRef]

27. Yu, J.; Ji, H.; Yang, Z.; Liu, A. Relationship between structural properties and antitumor activity of Astragalus polysaccharides extracted with different temperatures. Int. J. Biol. Macromol. 2018, 124, 469-477. [CrossRef]

28. Mummaleti, G.; Sarma, C.; Kalakandan, S.; Sivanandham, V.; Rawson, A.; Anandharaj, A. Optimization and extraction of edible microbial polysaccharide from fresh coconut inflorescence sap: An alternative substrate. LWT 2020, 138, 110619. [CrossRef]

29. Solmaz, H.; Ardebili, S.M.S.; Calam, A.; Yilmaz, E.; Ipci, D. Prediction of performance and exhaust emissions of a CI engine fueled with multi-wall carbon nanotube doped biodiesel-diesel blends using response surface method. Energy 2021, 227, 120518. [CrossRef]

30. Yu, J.; Dong, X.-D.; Jiao, J.-S.; Yu, S.-S.; Ji, H.-Y.; Liu, A.-J.; Chen, Y. Extraction, purification, and biological activities in vivo of a novel fructose-rich polysaccharide from Codonopsis pilosula. Ind. Crop. Prod. 2021, 176, 114309. [CrossRef]

31. Bu, X.; Xu, Y.; Zhao, M.; Li, D.; Zou, J.; Wang, L.; Bai, J.; Yang, Y. Simultaneous extraction of polysaccharides and polyphenols from blackcurrant fruits: Comparison between response surface methodology and artificial neural networks. Ind. Crop. Prod. 2021, 170, 113682. [CrossRef]

32. Glasauer, A.; Chandel, N.S. Targeting antioxidants for cancer therapy. Biochem. Pharmacol. 2014, 92, 90-101. [CrossRef] [PubMed]

33. Liou, G.-Y.; Storz, P. Reactive oxygen species in cancer. Free Radic. Res. 2010, 44, 479-496. [CrossRef] [PubMed]

34. Lv, Y.; Glahn, R.P.; Hebb, R.L.; Rizvi, S.S. Physico-chemical properties, phytochemicals and DPPH radical scavenging activity of supercritical fluid extruded lentils. LWT 2018, 89, 315-321. [CrossRef]

35. Abdullah, S.S.S.; Mazlan, A.N. Quantification of polyphenols and antioxidant activity in several herbal and green tea products in Malaysia. Mater. Today Proc. 2020, 31, A106-A113. [CrossRef]

36. Yin, D.; Sun, X.; Li, N.; Guo, Y.; Tian, Y.; Wang, L. Structural properties and antioxidant activity of polysaccharides extracted from Laminaria japonica using various methods. Process Biochem. 2021, 111, 201-209. [CrossRef]

37. Han, Y.; Zhao, M.; Ouyang, K.; Chen, S.; Zhang, Y.; Liu, X.; An, Q.; Zhao, Z.; Wang, W. Sulfated modification, structures, antioxidant activities and mechanism of Cyclocarya paliurus polysaccharides protecting dendritic cells against oxidant stress. Ind. Crop. Prod. 2021, 164, 113353. [CrossRef] 
38. Huo, X.-Z.; Wang, X.; Yang, R.; Qu, L.-B.; Zeng, H.-J. Studies on the effect of a Fupenzi glycoprotein on the fibrillation of bovine serum albumin and its antioxidant activity. Spectrochim. Acta Part A Mol. Biomol. Spectrosc. 2020, 237, 118387. [CrossRef]

39. Khosravi, M.; Poursaleh, A.; Ghasempour, G.; Farhad, S.; Najafi, M. The effects of oxidative stress on the development of atherosclerosis. Biol. Chem. 2018, 400, 711-732. [CrossRef]

40. Olsvik, P.; Kristensen, T.; Waagbo, R.; Rosseland, B.; Tollefsen, K.-E.; Baeverfjord, G.; Berntssen, M. mRNA expression of antioxidant enzymes (SOD, CAT and GSH-Px) and lipid peroxidative stress in liver of Atlantic salmon (Salmo salar) exposed to hyperoxic water during smoltification. Comp. Biochem. Physiol. Part C Toxicol. Pharmacol. 2005, 141, 314-323. [CrossRef]

41. Alyethodi, R.R.; Sirohi, A.S.; Karthik, S.; Tyagi, S.; Perumal, P.; Singh, U.; Sharma, A.; Kundu, A. Role of seminal MDA, ROS, and antioxidants in cryopreservation and their kinetics under the influence of ejaculatory abstinence in bovine semen. Cryobiology 2021, 98, 187-193. [CrossRef] [PubMed]

42. YouGuo, C.; ZongJi, S.; XiaoPing, C. Modulatory effect of Ganoderma lucidum polysaccharides on serum antioxidant enzymes activities in ovarian cancer rats. Carbohydr. Polym. 2009, 78, 258-262. [CrossRef]

43. Li, M.-Y.; Zhu, X.-M.; Niu, X.-T.; Chen, X.-M.; Tian, J.-X.; Kong, Y.-D.; Zhang, D.-M.; Zhao, L.; Wang, G.-Q. Effects of dietary Allium mongolicum Regel polysaccharide on growth, lipopolysaccharide-induced antioxidant responses and immune responses in Channa argus. Mol. Biol. Rep. 2019, 46, 2221-2230. [CrossRef] [PubMed]

44. Zhu, X.-M.; Liu, X.-Y.; Xia, C.-G.; Li, M.-Y.; Niu, X.-T.; Wang, G.-Q.; Zhang, D.-M. Effects of dietary Astragalus Propinquus Schischkin polysaccharides on growth performance, immunological parameters, antioxidants responses and inflammation-related gene expression in Channa argus. Comp. Biochem. Physiol. Part C Toxicol. Pharmacol. 2021, 249, 109121. [CrossRef]

45. Mizui, M. Natural and modified IL-2 for the treatment of cancer and autoimmune diseases. Clin. Immunol. 2018, 206, 63-70. [CrossRef]

46. Suzuki, A.; Leland, P.; Joshi, B.H.; Puri, R.K. Targeting of IL-4 and IL-13 receptors for cancer therapy. Cytokine 2015, 75, 79-88. [CrossRef]

47. Dash, S.; Sahu, A.K.; Srivastava, A.; Chowdhury, R.; Mukherjee, S. Exploring the extensive crosstalk between the antagonistic cytokines- TGF- $\beta$ and TNF- $\alpha$ in regulating cancer pathogenesis. Cytokine 2020, 138, 155348. [CrossRef]

48. Todorović-Raković, N. The role of cytokines in the evolution of cancer: IFN- $\gamma$ paradigm. Cytokine 2021, 151, 155442. [CrossRef]

49. Ren, L.; Zhang, J.; Zhang, T. Immunomodulatory activities of polysaccharides from Ganoderma on immune effector cells. Food Chem. 2020, 340, 127933. [CrossRef]

50. Han, C.; Wang, X.; Zhang, D.; Wei, Y.; Cui, Y.; Shi, W.; Bao, Y. Synergistic use of florfenicol and Salvia miltiorrhiza polysaccharide can enhance immune responses in broilers. Ecotoxicol. Environ. Saf. 2021, 210, 111825. [CrossRef] 